\title{
CHILDBEARING AND THE CHANGING NATURE OF PARENTHOOD: THE CONTEXTS, ACTORS, AND EXPERIENCES OF HAVING CHILDREN
}




\title{
CONTEMPORARY PERSPECTIVES IN FAMILY RESEARCH
}

\author{
Series editor: Sampson Lee Blair
}

\section{Recent Volumes:}

Volume 1: Through the Eyes of the Child Re-Visioning Children as Active Agents of Family Life - Edited by Michael Abrams, Johnson Matthey, B. A. Murrer, Felix M. Berardo, Constance L. Shehan, 2000

Volume 2: $\quad$ Families, Crime and Criminal Justice Charting the Linkages - Edited by Greer Litton Fox and Michael L. Benson, 2000

Volume 3: Minding the Time in Family Experience Emerging Perspectives and Issues - Edited by Kerry Daly, 2001

Volume 4: Intergenerational Ambivalences New Perspectives on Parent-Child Relations in Later Life - Edited by Karl A. Pillemer and Kurt K. Luscher, 2003

Volume 5: Families in Eastern Europe - Edited by Mihaela Robila, 2004

Volume 6: Economic Stress and the Family - Edited By Sampson Lee Blair, 2012

Volume 7: Visions of the 21st Century Family: Transforming Structures and Identities - Edited by Patricia Neff Claster and Sampson Lee Blair, 2013

Volume 8A: Family Relationships and Familial Responses to Health Issues Edited by Jennifer Higgins McCormick and Sampson Lee Blair, 2014

Volume 8B: Family and Health: Evolving Needs, Responsibilities, and Experiences - Edited by Sampson Lee Blair and Jennifer Higgins McCormick, 2014

Volume 9: Violence and Crime in the Family: Patterns, Causes, and Consequences - Edited by Sheila Royo Maxwell and Sampson Lee Blair, 2015

Volume 10: Divorce, Separation, and Remarriage: The Transformation of Family - Edited by Giovanna Gianesini and Sampson Lee Blair 2017

Volume 11: Intimate Relationships and Social Change: The Dynamic Nature of Dating, Mating, and Coupling - Edited by Christina L. Scott and Sampson Lee Blair 2018

Volume 12: Fathers, Childcare and Work - Edited By Arianna Santero and Rosy Musumeci, 2018

Volume 13: The Work-Family Interface: Spillover, Complications, and Challenges - Edited by Sampson Lee Blair and Josip Obradović, 2018 


\title{
Childbearing and the Changing Nature of Parenthood: The Contexts, Actors, and Experiences of Having Children
}

\author{
EDITED BY \\ ROSALINA PISCO COSTA
}

Universidade de Évora, Portugal

SAMPSON LEE BLAIR

State University of New York at Buffalo, USA

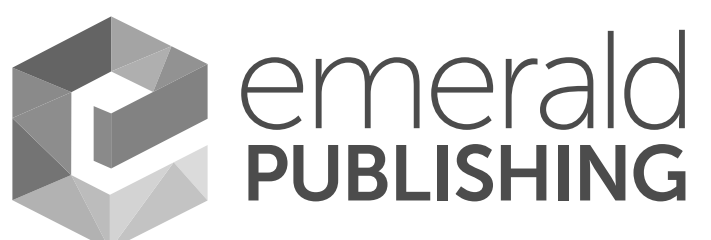

United Kingdom - North America - Japan

India - Malaysia - China 
Emerald Publishing Limited

Howard House, Wagon Lane, Bingley BD16 1WA, UK

First edition 2020

Copyright (C) 2020 Emerald Publishing Limited

Reprints and permissions service

Contact: permissions@emeraldinsight.com

No part of this book may be reproduced, stored in a retrieval system, transmitted in any form or by any means electronic, mechanical, photocopying, recording or otherwise without either the prior written permission of the publisher or a licence permitting restricted copying issued in the UK by The Copyright Licensing Agency and in the USA by The Copyright Clearance Center. Any opinions expressed in the chapters are those of the authors. Whilst Emerald makes every effort to ensure the quality and accuracy of its content, Emerald makes no representation implied or otherwise, as to the chapters' suitability and application and disclaims any warranties, express or implied, to their use.

British Library Cataloguing in Publication Data

A catalogue record for this book is available from the British Library

ISBN: 978-1-83867-067-2 (Print)

ISBN: 978-1-83867-066-5 (Online)

ISBN: 978-1-83867-068-9 (Epub)

ISSN: 1530-3535 (Series)

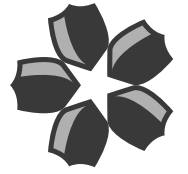

SOQAR certified

Management System,

awarded to Emerald

for adherence to

Environmental

ISOQAR

standard

REGISTERED

ISO 14001:2004.

Certificate Number 1985

ISO 14001

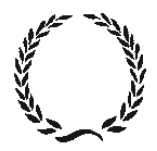

INVESTOR IN PEOPLE 


\section{EDITORIAL BOARD}

\author{
Anja-Kristin Abendroth \\ Bielefeld University, Germany \\ Clarence M. Batan \\ University of Santo Tomas, Philippines \\ Eli Buchbinder \\ University of Haifa, Israel \\ Yu-Hua Chen \\ National Taiwan University, Taiwan
}

Patricia Neff Claster

Edinboro University, USA

Teresa M. Cooney

University of Colorado-Denver, USA

Rosalina Pisco Costa

University of Évora, Portugal

Alda Britto da Motta

Federal University of Bahia, Brazil

Giovanna Gianesini

University of Bologna, Italy

Ana Josefina Cuevas Hernandez

University of Colima, Mexico

\author{
Bryndl Hohmann-Marriott \\ University of Otago, New Zealand \\ Cardell K. Jacobson \\ Brigham Young University, USA \\ Josip Obradović \\ University of Zagreb, Croatia \\ Olufemi Adeniyi Fawole \\ University of Ilorin, Nigeria \\ Matthias Pollman-Schult \\ Social Science Research Center Berlin, \\ Germany
}

Ria Smit

University of Johannesburg, South

Africa

Helen M. Stallman

University of South Australia,

Australia

Fleur Thomése

VU University, Amsterdam, The

Netherlands 
This page intentionally left blank 


\section{CONTENTS}

About the Contributors ix

Foreword $x v$

Chapter 1 Putting Gender on Ice: Preserving Motherhood in Media Coverage of Elective Egg and Sperm Freezing Ashlyn M. Jaeger

Chapter 2 Becoming Mum: Exploring the Emergence and Formulation of a Mother's Identity During the Transition into Motherhood

Samantha Reveley

Chapter 3 Contextual Influences on Contraception Use Among Poor Women in Pakistan

Hassan Raza, Brad van Eeden-Moorefield, Soyoung Lee

and Lisa Lieberman

Chapter 4 Doing Becoming a Mother: The Gendering of Parenthood in Birth-preparation Classes in Germany

Marion Müller, Nicole Zillien and Julia Gerstewitz

Chapter 5 Midwives in Ontario Hospitals: The Mainstreaming of "Alternative" Childbearing Melodie Cardin

Chapter 6 The Medicalization of Pregnancy and Childbirth in Contemporary Turkey: The Effect of Risk Discourses for Turkish Women's Experiences

Zehra Zeynep Sadıkoğlu

Chapter 7 Going it Alone: A Multigenerational Investigation of Women's Perceptions of Single Mothers by Choice Versus Circumstance

Christina L. Scott, Siri Wilder and Justine Bennett

Chapter 8 Building a Family within a Non-Heterosexual Couple: Struggles, Fears, Representations and Practices Filomena Santos and Rita Dias 
Chapter 9 A Qualitative Inquiry: Reflections on Pregnancy, Birth, and Transition to Parenthood Experiences of African-American Couples with a Toddler Son

Sheresa Boone Blanchard and Tacy Rae LeBaron

Index 